\title{
SISTEM PENDUKUNG KEPUTUSAN PENERIMAAN KARYAWAN MENGGUNAKAN ALGORITMA MULTIFACTOR EVALUATION PROCESS (STUDI KASUS: XYZ DEPARTMENT STORE REGIONAL PRIANGAN TIMUR)
}

\author{
Lia Amelia ${ }^{1}$, Rahmi Nur Shofa ${ }^{2}$, Rianto $^{3}$ \\ Informatika Universitas Siliwangi Tasikmalaya ${ }^{1,2,3}$ \\ 167006049@student.unsil.ac.id ${ }^{1}$,rahmi.shofa@unsil.ac.id², rianto@unsil.ac.id ${ }^{3}$
}

\begin{abstract}
ABSTRAK
Pengelolaan sumber daya manusia suatu perusahaan mempengaruhi banyak aspek penentu keberhasilan dari perusahaan tersebut, salah satu upaya yang dilakukan adalah seleksi dalam penerimaan karyawan. Berdasarkan hasil wawancara, XYZ Depstore dalam proses penerimaan kayawannya dilakukan per-regional dan masih dilaksanakan secara manual dengan bobot kriteria yang belum terperinci, hal ini menimbulkan beberapa masalah diantaranya memerlukan waktu yang banyak, terjadinya human error yang menyebabkan perhitungan tidak adil dan tidak akurat. Sehingga dibutuhkan sistem dengan algoritma tertentu yang meranking otomatis calon karyawan dengan akurat, adil dan lebih cepat diantara banyaknya pelamar. Dalam pembangunan sistem digunakan algoritma Multifactor Evaluation Process (MFEP) dengan tiga kriteria dan bobotnya yang telah ditentukan, yaitu dokumen $20 \%$, psikotes $10 \%$ dan wawancara $70 \%$. Metode pengembangan sistem yang digunakan adalah extreme programming. Sistem menghasilkan urutan rekomendasi calon karyawan yang layak diterima untuk membantu pihak perusahaan mengambil keputusan. Dilengkapi juga dengan fitur untuk calon karyawan mengajukan dokumen lamaran dan data diri secara online, informasi lowongan kerja, pengumuman seleksi dan pembuatan laporan. Pengujian fungsional pada sistem dilakukan dengan metode black box, menunjukan hasil berjalannya semua skenario yang telah dibuat. Hasil perhitungan pada sistem dibandingkan dengan hasil perhitungan pada microsoft excel menggunakan 30 alternatif calon karyawan, menunjukan hasil perhitungan yang sama, sehingga tingkat akurasi sebesar $100 \%$.
\end{abstract}

Kata Kunci: Multifactor Evaluation Process, Penerimaan Karyawan, Seleksi Karyawan, Sistem Pendukung Keputusan

\begin{abstract}
The management of human resources in a company affects many aspects that determine the success of the company. One of the efforts made is the selection of employees. Based on the interview results, $\mathrm{XYZ}$ Depstore in the process of recruiting employees is carried out regionally and is still carried out manually with the weight of the criteria that have not been detailed, this raises several problems including requiring a lot of time, the occurrence of human errors which cause unfair and inaccurate calculations. So that we need a system with a certain algorithm that automatically ranks prospective employees with accuracy, fairness and faster among the many applicants. In developing the system, the Multifactor Evaluation Process (MFEP) algorithm is used with three criteria and its weights that have been determined, namely $20 \%$ document, $10 \%$ psychological test and $70 \%$ interview. The system development method used is extreme programming. The system generates a sequence of recommendations for candidate employees who deserve to be accepted to help the company make decisions. Also equipped with features for prospective employees to submit application documents and personal data online, job vacancies information, selection announcements and report generation. Functional testing of the system is carried out using the black box method, showing the results of all the scenarios that have been made. The results of the calculation on the system are compared with the
\end{abstract}


results of calculations on Microsoft Excel using 30 alternative prospective employees, showing the same calculation results, so that the accuracy rate is $100 \%$.

Keywords: Decision Support System, Employee Acceptance, Employee Selection, Multifactor Evaluation Process

\section{PENDAHULUAN}

PT. XYZ adalah perusahaan ritel modern asli Indonesia dengan format supermarket dan department store yang terus berkembang dari tahun 1982. Sebuah perusahaan yang sedang berkembang harus memiliki manajemen yang baik dan terstruktur, manajemen yang baik berasal dari sumber daya yang baik. Pengelolaan sumber daya manusia dari suatu perusahaan sangat mempengaruhi banyak aspek penentu keberhasilan kerja dari perusahaan tersebut (Wahyudi, 2016). Salah satu upaya pengelolaan sumber daya manusia adalah dengan dilakukannya proses penerimaan karyawan yang sesuai dengan kriteria kekosongan jabatan yang akan diisi.

Berdasarkan wawancara dengan pihak staff recruitment regional priangan timur, Selama ini proses penilaian rekrut pada XYZ depstore masih dilakukan secara manual dengan bobot kriteria yang belum terperinci. Pemilihan calon karyawan ini menjadi sesuatu yang sulit saat jumlah pendaftar banyak dari berbagai ragam latar belakang serta kriteria-kriteria penerimaan yang ditetapkan terkadang komplek. Dalam hal ini pengambilan keputusan memerlukan perhitungan yang akurat, adil dan cepat diantara banyaknya pelamar. Perhitungan ini memerlukan sebuah sistem dengan algoritma tertentu yang secara otomatis merangking setiap calon karyawan berdasarkan kriteriakriteria yang ditetapkan

Penelitian ini mengusulkan proses seleksi menggunakan algoritma Multifactor Evaluation Process (MFEP). Sistem menunjukan akurasi sebesar 99,99\% dalam melakukan penentuan pemenang tender proyek dengan metode MFEP. Ningsih et al. (2019)
Berdasarkan latar belakang masalah, rumusan masalah dalam penelitian ini adalah:

(1) Bagaimana membangun sistem pendukung keputusan dengan menerapkan algoritma Multifactor Evaluation Process (MFEP) ?

(2) Bagaimana tingkat akurasi perhitungan sistem pendukung keputusan penerimaan karyawan dengan menerapkan algoritma Multifactor Evaluation Process (MFEP)?

Tujuan yang ingin dicapai berdasarkan rumusan masalah penelitian ini adalah sebagai berikut:

(1) Membangun sistem pendukung keputusan dengan menerapkan algoritma Multifactor Evaluation Process (MFEP) dalam membantu pihak perusahaan mengambil keputusan untuk menentukan calon karyawan yang layak.

(2) Menghitung tingkat akurasi perhitungan sistem pendukung keputusan penerimaan karyawan dengan menerapkan algoritma Multifactor Evaluation Process (MFEP).

Hasil dari penelitian ini diharapkan dapat membantu pihak perusahaan dalam mengambil keputusan untuk menentukan siapa yang layak diterima sebagai karyawan berdasarkan kriteria yang ditentukan dengan melihat nilai prioritas dari masing-masing calon karyawan. 


\section{METODE PENELITIAN}

Metodologi dalam penyelesaian masalah digambarkan dalam langkah-langkah sebagai berikut:

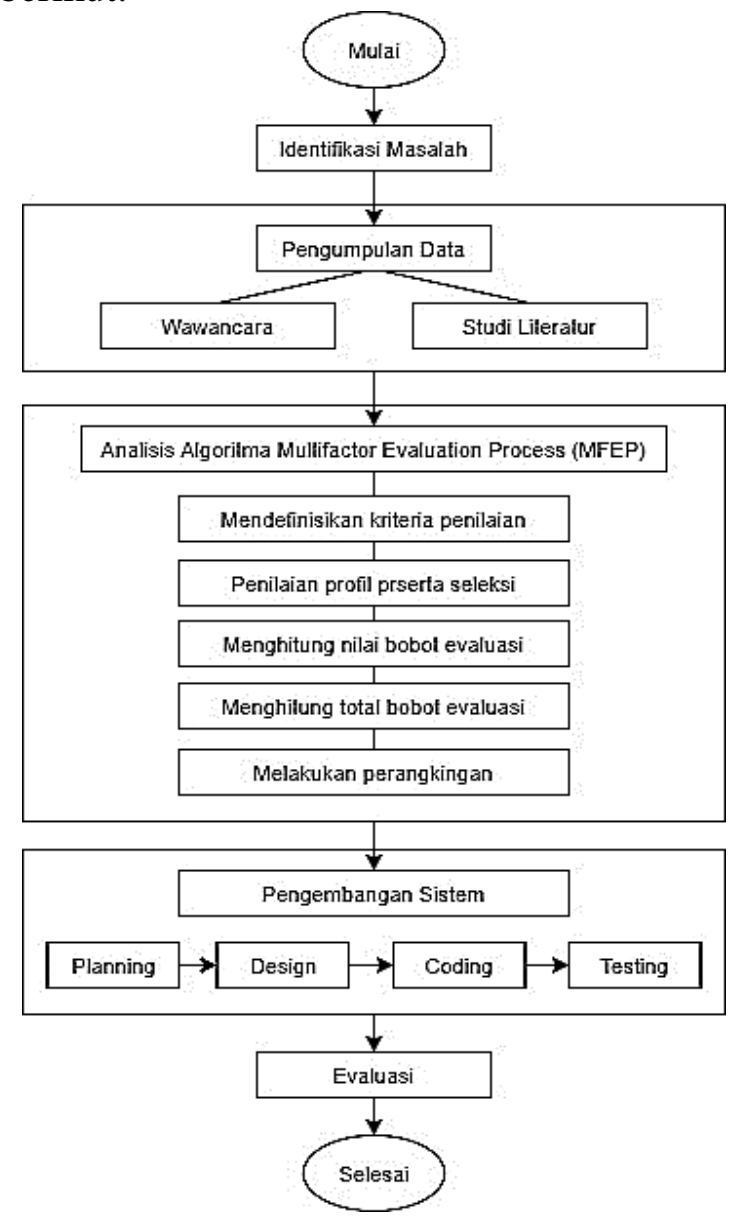

Gambar 1. Metodologi Penelitian

Penelitian dilakukan dengan tahapan sebagai berikut:

\section{A. Identifikasi Masalah}

Identifikasi masalah merupakan langkah awal untuk mengetahui permasalahan yang sesuai dengan tema atau topik penelitian, maka dilakukan identifikasi masalah melalui proses pengenalan, pengamatan dan diskusi terhadap tempat studi kasus.

\section{B. Pengumpulan Data}

Langkah selanjutnya adalah mengumpulan data untuk mendapatkan solusi yang tepat. Berikut 2 teknik pengumpulan data yang digunakan:
1. Wawancara, kegiatan ini dilakukan dengan staff dari perusahaan, yang terlibat atau berhubungan dengan masalah dan bahasan.

2. Studi litelatur, dilakukan dengan mempelajari referensi lain seperti buku, artikel, jurnal, makalah maupun melalui media internet yang berkaitan dengan permasalahan, untuk menunjang pencapaian tujuan penelitian.

\section{Analisis Algoritma Multifactor Evaluation Process \\ Analisis algoritma Multifactor} Evaluation Process merupakan tahapan proses analisis terhadap cara kerja dari algoritma pengurutan Multifactor Evaluation Process. Penyelesaian dari algoritma Multifator Evaluation Process menurut Kaswidjanti et al. (2019) yaitu :

1 Mendefinisikan kriteria penilaian;

2 Melakukan penilaian profil peserta seleksi;

3 Menghitung nilai bobot evaluasi (NBE).

Rumus weight evaluation ini ditunjukkan dengan persamaan (1) sebagai berikut:

$$
\mathrm{WE}=\mathrm{FW} \times \mathrm{E}
$$

Dimana :

WE : Nilai bobot evaluasi

FW : Nilai bobot faktor

E : Nilai faktor evaluasi

4. Menghitung total bobot evaluasi (TBE) Rumus total weight evaluation ini ditunjukkan dengan persamaan 2 sebagai berikut:

$$
\sum_{i=1}^{n} \mathrm{WEi}=\mathrm{WE} 1+\mathrm{WE} 2+\mathrm{WE} 3+\cdots+\mathrm{Wn}
$$

Dimana :

$\sum$ WEi : Total nilai bobot evaluasi

WE : Nilai Bobot Evaluasi

5. Melakukan perangkingan untuk mendapatkan hasilnya. 


\section{Pengembangan Sistem}

Metode pengembangan sistem yang digunakan adalah Extreme Programming (XP), salah satu model yang ada pada agile software development. Extreme programming menggunakan pendekatan berorientasi objek. Pengembangan ini mencakup didalamnya seperangkat aturan dan praktik-praktik yang terjadi dalam kontek empat kegiatan kerangka kerja yaitu planning, design, coding, dan testing (Pressman, 2012).

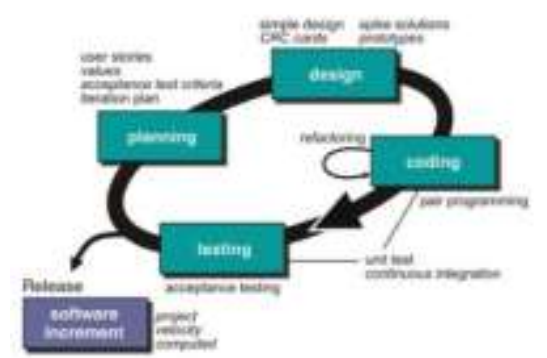

Gambar 2. Metode Pengembangan Sistem Extreme Programming

\section{E. Evaluasi}

Evaluasi dilakukam untuk mengukur dan menilai apakah sistem pendukung keputusan penerimaan karyawan yang dibuat memiliki tingkat akurasi yang tinggi sehingga dapat digunakan sesuai dengan kebutuhan dan menjadi solusi untuk mengatasi permasalahan yang ada.

\section{HASIL DAN PEMBAHASAN}

\section{A. Identifikasi Masalah}

PT.XYZ memiliki banyak karyawan yang tersebar di seluruh cabangnya dan rutin melakukan penerimaan karyawan baru. Dalam melakukan proses penerimaan karyawan ini dilakukan pembagian perregional. Prosesnya masih dilakukan secara manual dengan bobot kriteria yang belum terperinci, hal ini menimbulkan beberapa masalah diantaranya jumlah pendaftar yang banyak dengan berbagai latar belakang yang berbeda terkadang menjadi sesuatu yang sulit saat pemilihan dilakukan secara manual, memerlukan waktu yang banyak dalam prosesnya, terjadinya human error yang menyebabkan perhitungan yang tidak akurat dan tidak adil diantara banyaknya pelamar.

Maka dibangun sebuah sistem dengan algoritma Multifactor Evaluation Process yang secara otomatis meranking setiap calon karyawan dengan perhitungan yang akurat dan adil berdasarkan kriteria-kriteria yang ditetapkan, untuk kemudian dijadikan sebagai rekomendasi pihak staff recruitment perusahaan memilih calon karyawan yang layak untuk diterima bekerja. Pada algoritma ini akan diberikan pertimbangan yang subjektif terhadap faktor yang dianggap penting, maka penentuan bobot yang tepat akan menghasilkan keputusan tepat sasaran.

\section{B. Pengumpulan Data}

Pengumpulan data diawali melalui proses tanya jawab dengan pihak perusahaan $\mathrm{XYZ}$ depstore. Wawancara pertama dilaksanakan dengan staff people develover department regional priangan timur. Menghasilkan informasi mengenai gambaran umum perusahaan

Wawancara kedua dilaksanakan dengan staff recruitment regional priangan timur. Menghasilkan informasi mengenai pola dan prosedur penerimaan karyawan.

\section{Analisis Algoritma Multifactor Evaluation Process}

1. Mendefinisikan Kriteria/Faktor Penilaian Pada tabael 1 disajikan kriteria dan bobot kriteria yang dibutuhkan dalam penentuan penerimaan karyawan, sesuai dengan hasil wawancara yang sebelumnya dilakukan. Dimana jumlah bobot dari seluruh kriteria adalah 1 .

Tabel 1 Kriteria dan Bobot Kriteria

\begin{tabular}{ccc}
\hline $\begin{array}{c}\text { Kode } \\
\text { Kriteria }\end{array}$ & Nama Kriteria & Bobot Kriteria \\
\hline K01 & Dokumen & 0,2 \\
K02 & Psikotes & 0,1 \\
K03 & Wawancara & 0,7 \\
& Total & 1 \\
\hline
\end{tabular}




\section{Penilaian Profil Peserta Seleksi}

Pada langkah ini dilakukan penilaian profil calon karyawan, setiap calon karyawan akan diberikan penilaian untuk masingmasing kriteria. Penilaian dapat diberikan dengan range 1-100. Pada tabel 2 disajikan hasil penilaian yang diujikan kepada lima peserta seleksi.

Tabel 2 Penilaian Profil Peserta Seleksi

\begin{tabular}{ccccc}
\hline \multirow{2}{*}{ No } & \multirow{2}{*}{ Peserta } & \multicolumn{3}{c}{ Kode Kriteria } \\
\cline { 3 - 5 } & & K01 & K02 & K03 \\
\hline 1 & A & 80 & 85 & 70 \\
2 & B & 90 & 75 & 90 \\
3 & C & 95 & 70 & 85 \\
4 & D & 85 & 100 & 95 \\
5 & E & 80 & 95 & 80 \\
\hline
\end{tabular}

3. Menghitung Nilai Bobot Evaluasi

Selanjutnya menghitung bobot evaluasi. Bobot evaluasi dihitung menggunakan persamaan 1. Pada tabel 3 disajikan perhitungan bobot evaluasi untuk setiap peserta.

Tabel 3 Menghitung Nilai Bobot Evaluasi

\begin{tabular}{cccccc}
\hline $\begin{array}{c}\text { Pes- } \\
\text { erta }\end{array}$ & $\begin{array}{c}\text { Kode } \\
\text { Krite- } \\
\text { ria }\end{array}$ & $\begin{array}{c}\text { Bobot } \\
\text { Kriteria }\end{array}$ & $\begin{array}{c}\text { Nilai } \\
\text { Profil } \\
\text { Peserta }\end{array}$ & $\begin{array}{c}\text { Nilai } \\
\text { Bobot } \\
\text { Evalu- } \\
\text { asi }\end{array}$ \\
\hline \multirow{3}{*}{ A } & K01 & 0,2 & x & 80 & 16 \\
& K02 & 0.1 & x & 85 & 8,5 \\
& K03 & 0,7 & x & 70 & 49 \\
& K01 & 0,2 & x & 90 & 18 \\
B & K02 & 0.1 & x & 75 & 7,5 \\
& K03 & 0,7 & x & 90 & 62,99 \\
& K01 & 0,2 & x & 95 & 19 \\
C & K02 & 0.1 & x & 70 & 7 \\
& K03 & 0,7 & x & 85 & 59,49 \\
D & K01 & 0,2 & x & 85 & 17 \\
& K02 & 0.1 & x & 100 & 10 \\
& K03 & 0,7 & x & 95 & 66,50 \\
E & K01 & 0,2 & x & 80 & 16 \\
& K02 & 0.1 & x & 95 & 9,5 \\
& K03 & 0,7 & x & 80 & 56 \\
\hline
\end{tabular}

4. Menghitung Total Bobot Evaluasi

Total bobot evaluasi dihitung dengan persamaan 2. Hasil total bobot evaluasi untuk masing-masing peserta disajikan dalam tabel 4.4 berikut :
Tabel 4 Menghitung Total Bobot Evaluasi

\begin{tabular}{cccccccc}
\hline \multirow{2}{*}{ Peserta } & \multicolumn{3}{c}{ Nilai Bobot Evaluasi } & Total \\
\cline { 2 - 5 } & K01 & & K02 & & K03 & $\begin{array}{c}\text { Bobot } \\
\text { Evaluasi }\end{array}$ \\
\hline $\mathrm{A}$ & 16 & + & 8,5 & + & 49 & 73,50 \\
$\mathrm{~B}$ & 18 & + & 7,5 & + & 62,99 & 88,49 \\
$\mathrm{C}$ & 19 & + & 7 & + & 59,49 & 85,49 \\
$\mathrm{D}$ & 17 & + & 10 & + & 66,50 & 93,50 \\
$\mathrm{E}$ & 16 & + & 9,5 & + & 56 & 81,50 \\
\hline
\end{tabular}

5. Melakukan Perankingan

Perankingan, dilakukan dengan mengurutkan nilai total bobot evaluasi dari nilai yang terbesar. Perankingan disajikan dalam tabel 5 sebagai berikut:

Tabel 5 Perankingan

\begin{tabular}{cccccc}
\hline \multirow{2}{*}{$\begin{array}{c}\text { Pes- } \\
\text { erta }\end{array}$} & \multicolumn{2}{c}{ Nilai Bobot Evaluasi } & $\begin{array}{c}\text { Total } \\
\text { Bobot } \\
\text { Evaluasi }\end{array}$ & $\begin{array}{c}\text { Ran- } \\
\text { king }\end{array}$ \\
\hline D & 17 & 10 & 66,50 & 93,50 & 1 \\
B & 18 & 7,5 & 62,99 & 88,49 & 2 \\
C & 19 & 7 & 59,49 & 85,49 & 3 \\
E & 16 & 9,5 & 56 & 81,50 & 4 \\
A & 16 & 8,5 & 49 & 73,50 & 5 \\
\hline
\end{tabular}

\section{Pengembangan Sistem}

\section{Planning}

XYZ depstore membutuhkan sebuah sistem dengan algoritma tertentu yang secara otomatis meranking setiap calon karyawan dengan perhitungan yang akurat dan adil berdasarkan kriteria-kriteria yang ditetapkan. Dibutuhkan pula sistem dimana calon karyawan dapat mengajukan dokumen lamaran dan data diri secara online, serta fitur-fitur pendukung lain seperti fitur untuk menginformasikan lowongan kerja, fitur untuk mengirimkan pengumuman seleksi dan pembuatan laporan.

\section{Design}

a. Use Case Diagram

Use case diagram menggambarkan interaksi aktor dengan sistem. Super admin memiliki hak akses penuh untuk mengelola sistem, termasuk didalamnya mengelola admin. Interaksi super admin dengan sistem dijabarkan pada gambar 3 . 


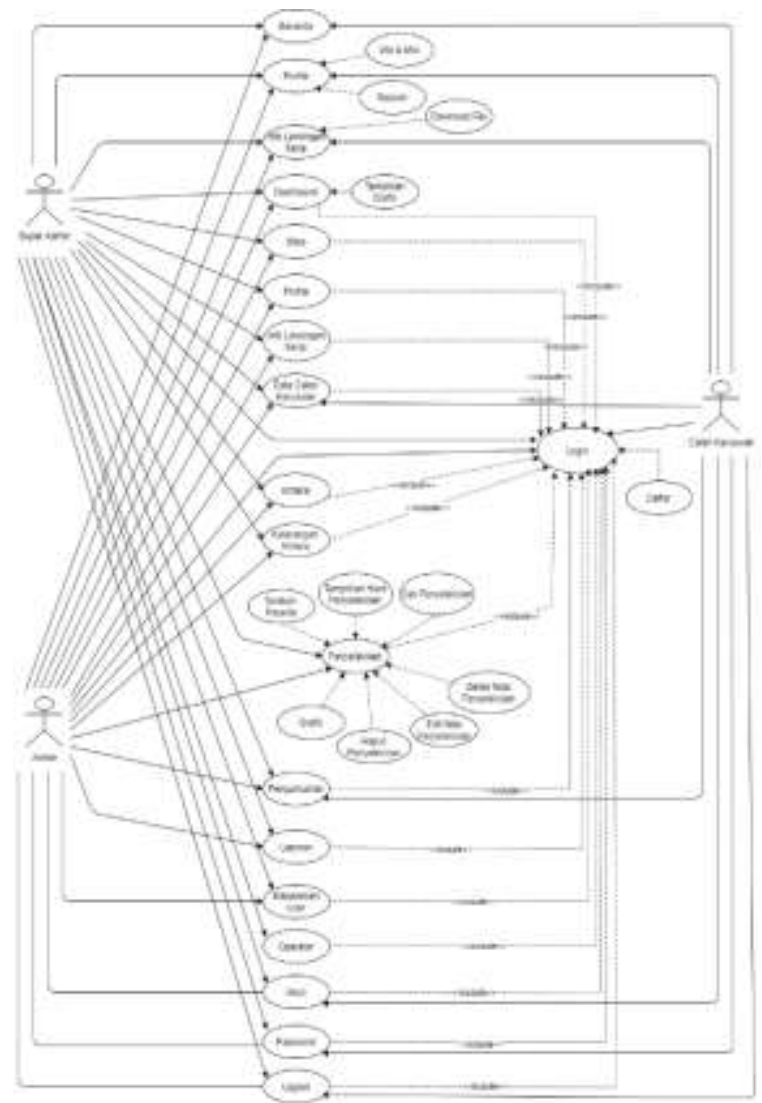

Gambar 3. Use Case Diagram Super Admin

\section{b. Sequence Diagram}

Sequence diagram menjelaskan interaksi objek yang berdasarkan urutan waktu. Dalam gambar 4 dijabarkan sequence diagram untuk login super admin dan admin. Login dimulai dengan super admin/admin menginputkan username dan password, sistem akan memproses, apabila username dan password valid akan diarahkan ke halaman dashboard, sebaliknya jika tidak valid maka sistem akan menampilkan pesan kesalahan.

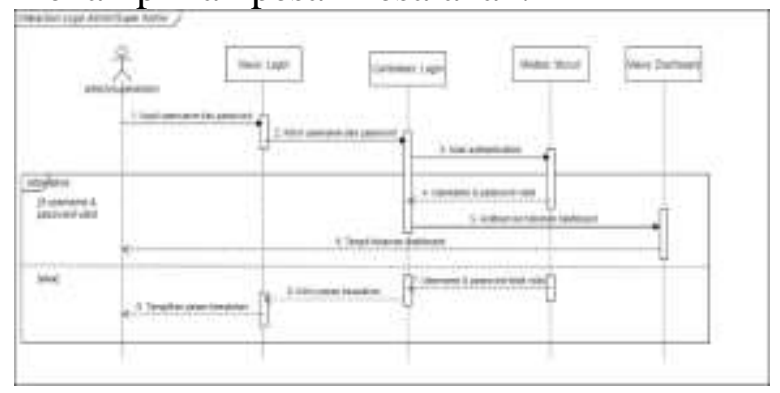

Gambar 4. Sequence Diagram Login Super Admin dan Admin

\section{c. Activity Diagram}

Activity diagram dapat memodelkan proses-proses apa saja yang terjadi pada sistem. Dalam gambar 5 dijabarkan activity diagram login super admin dan admin. Aktivitas pertama yang dilakukan yaitu memilih menu login, maka halaman login akan ditampilkan, kemudian input username dan password untuk selanjutnya dilakukan proses autentikasi, apabila valid diarahkan ke halaman dashboard, jika tidak valid terdapat pesan kesalahan.

Gambar 5. Activity Diagram Login Super Admin dan Admin

\section{d. Class Diagram}

Class diagram digunakan untuk menampilkan kelas-kelas yang ada pada suatu sistem dan hubungannya. Terdapat 12 class yang dibuat pada sistem ini, dimana class manajemen user, operator dan karyawan merupakan relasi waris dari class users. Sedangkan class profil, slide, info lowker dan kriteria merupakan relasi waris dari class web. Class penyeleksian merupakan kompisisi dari class kriteria, sedangkan class pengumuman dan laporan merupakan komposisi dari class penyeleksian. Dan asosiasi dari class diagram ini users mengakses web. Class diagram disajikan dalam gambar 6. 


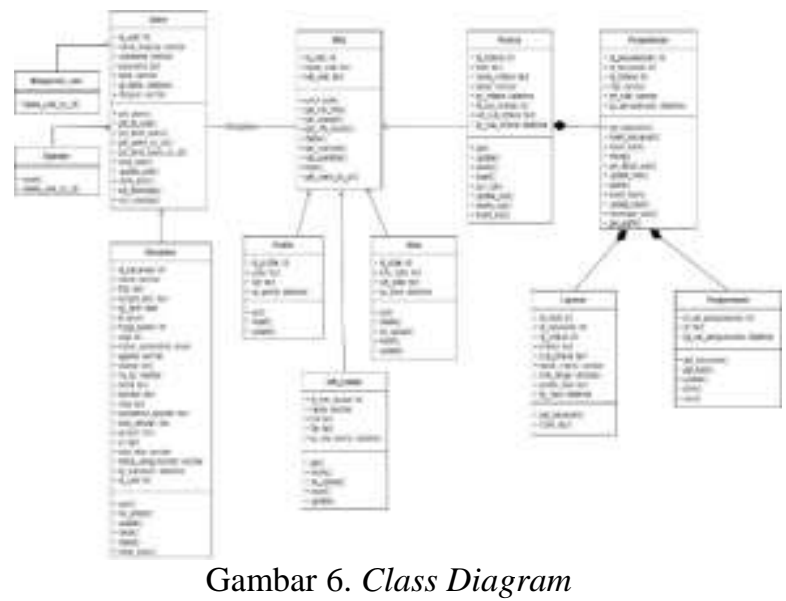

\section{e. Rancangan Interface}

Perancangan interface merupakan mekanisme komunikasi antara pengguna dengan sistem, dapat menerima dan memberikan informasi kepada pengguna untuk membantu mengerahkan alur penelusuran masalah hingga ditemukannya suatu solusi. Pada gambar 7 disajikan rancangan interface menu dashboard, pada dashboard ini dapat dilihat grafik penyeleksian berdasarkan tanggal.

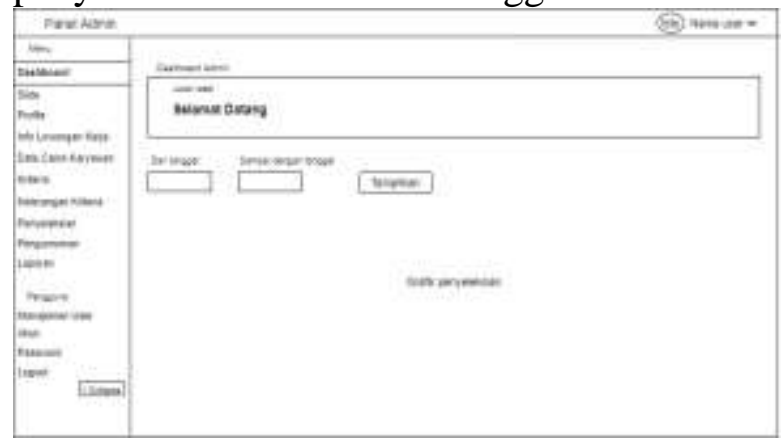

Gambar 7. Rancangan Interface Dashboard

\section{Coding}

Kode program perhitungan algoritma Multifactor Evaluation Process terdapat dalam menu penyeleksian pada level pengguna super admin dan admin. Saat super admin atau admin menambahkan peserta seleksi dan menginputkan nilai profil peserta seleksi, sistem akan melakukan perhitungan dengan algoritma Multifactor Evaluation Process sesuai dengan bobot kriteria yang sebelumnya sudah ditentukan. Sistem akan menampilakn hasil perankingan yaitu urutan prioritas calon karyawan yang layak diterima. Seperti yang tertera pada gambar 8 .

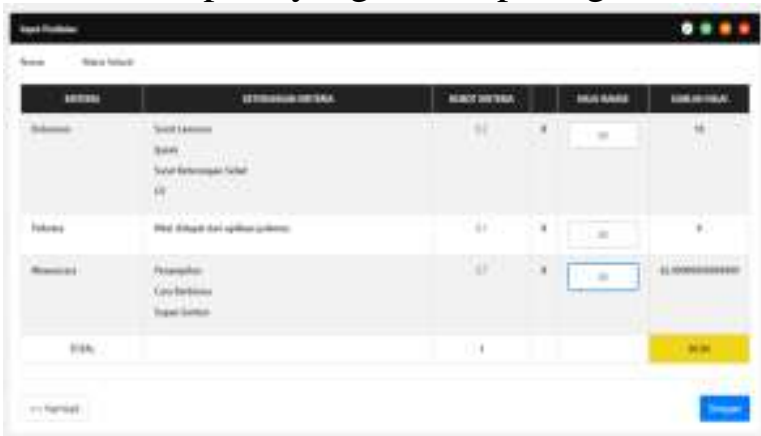

Gambar 8. Perhitungan Algoritma MFEP pada

Sistem

\section{Testing}

Pengujian perangkat lunak dilakukan dengan metode blackbox testing. Dilakukan dengan cara memberikan sejumlah input pada program. Input tersebut kemudian diproses sesuai dengan kebutuhan fungsionalnya untuk melihat apakah program aplikasi dapat menghasilkan output yang sesuai dengan yang diinginkan dan sesuai pula dengan fungsi dasar dari program tersebut.

Pengujian menampilkan hasil seleksi tertera pada tabel 6 sebagai berikut:

Tabel 6 Pengujian Menampilkan Hasil Seleksi

\begin{tabular}{cccc}
\hline Input & $\begin{array}{c}\text { Hasil yang } \\
\text { Diharap- } \\
\text { kan }\end{array}$ & Output & $\begin{array}{c}\text { Kesim- } \\
\text { pulan }\end{array}$ \\
\hline Menampil- & Data & \\
Mengisi & kan data & peserta & \\
tanggal & peserta & seleksi & \\
kemudian & seleksi & sesuai & Berhasil \\
klik & sesuai & dengan & \\
tampilkan & dengan & tanggal & \\
& tanggal yang & yang & \\
& diinputkan & diinputkan & \\
\hline
\end{tabular}

Pengujian menampilakan hasil seleksi yaitu data peserta sesuai dengan tanggal yang diinputkan tertera pada gambar 9 . 


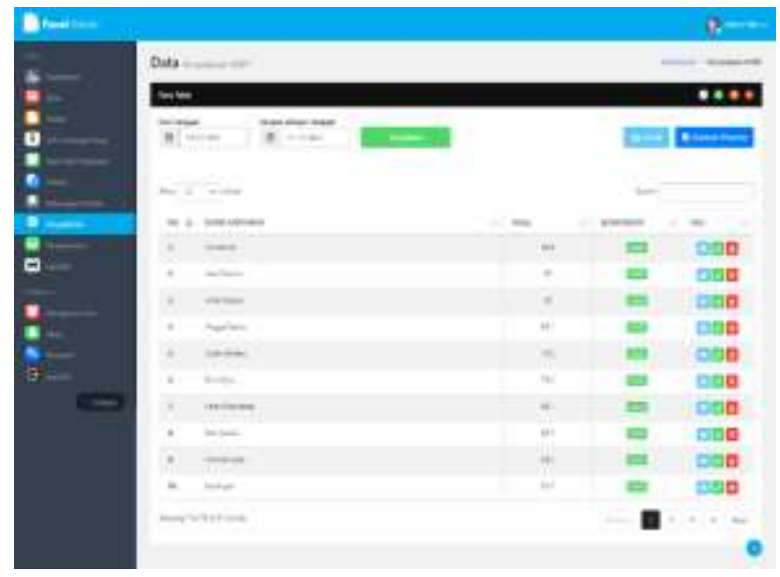

Gambar 9. Pengujian Menampilkan Hasil Seleksi

\section{E. Evaluasi}

Untuk mengetahui tingkat akurasi perhitungan sistem, maka dilakukan perbandingan antara perhitungan pada microsoft excel dengan hasil perhitungan pada sistem, sejalan dengan proses perhitungan pada XYZ Depstore yang masih menggunakan microsoft excel. Perbandingan dilakukan pada 30 peserta dengan data tiruan. Kriteria dan bobot kriteria yang digunakan sesuai pada tabel 1 .

Hasil perhitungan algoritma Multifactor Evaluation Process menggunakan microsoft excel tertera pada tabel 7. Dimana terdapat Nilai Profil Peserta (NPP), Nilai Bobot Evaluasi (NBE) dan Total Bobot Evaluasi (TBE).

Tabel 7. Hasil Perhitungan pada Microsoft Excel

\begin{tabular}{ccccc}
\hline Peserta & NPPP & NBE & TBE & $\begin{array}{c}\text { Ran- } \\
\text { king }\end{array}$ \\
\hline Rizki & 80 & 16,0 & & \\
Ramadhan & 80 & 8,0 & 90,50 & 1 \\
& 95 & 66,5 & & \\
Lydia & 90 & 18,0 & & \\
Sarah & 80 & 8,0 & 90,40 & 2 \\
& 92 & 64,4 & & \\
Ahmed Ali & 70 & 18,0 & & \\
& 92 & 64,0 & 89,40 & 3 \\
Hanna & 87 & 17,4 & & \\
Puspa & 88 & 8,8 & 89,20 & 4 \\
& 90 & 63,0 & & \\
\hline
\end{tabular}

Tabel 7. Hasil Perhitungan pada Microsoft Excel (Lanjutan 1)

\begin{tabular}{|c|c|c|c|c|}
\hline Peserta & NPPP & NBE & TBE & $\begin{array}{l}\text { Ran- } \\
\text { king }\end{array}$ \\
\hline \multirow{3}{*}{$\begin{array}{c}\text { Farah } \\
\text { Mandasari }\end{array}$} & 90 & 18,0 & \multirow{3}{*}{88,70} & \multirow{3}{*}{5} \\
\hline & 70 & 7,0 & & \\
\hline & 91 & 63,7 & & \\
\hline \multirow{3}{*}{$\begin{array}{c}\text { Alika } \\
\text { Rahayu }\end{array}$} & 85 & 17,0 & \multirow{3}{*}{86,00} & \multirow{3}{*}{6} \\
\hline & 67 & 6,7 & & \\
\hline & 89 & 62,3 & & \\
\hline \multirow{3}{*}{$\begin{array}{c}\text { Febi } \\
\text { Pratiwi }\end{array}$} & 86 & 17,2 & \multirow{3}{*}{85,70} & \multirow{3}{*}{7} \\
\hline & 90 & 9,0 & & \\
\hline & 85 & 59,5 & & \\
\hline \multirow{3}{*}{$\begin{array}{l}\text { Angga } \\
\text { Darius }\end{array}$} & 88 & 17,6 & \multirow{3}{*}{82,10} & \multirow{3}{*}{8} \\
\hline & 85 & 8,5 & & \\
\hline & 80 & 56,0 & & \\
\hline \multirow{3}{*}{$\begin{array}{c}\text { Teguh } \\
\text { Anugrah }\end{array}$} & 86 & 17,2 & \multirow{3}{*}{82,00} & \multirow{3}{*}{9} \\
\hline & 95 & 9,5 & & \\
\hline & 79 & 55,3 & & \\
\hline \multirow{3}{*}{$\begin{array}{c}\text { Yuni } \\
\text { Vanesa }\end{array}$} & 98 & 19,6 & \multirow{3}{*}{81,80} & \multirow{3}{*}{10} \\
\hline & 76 & 7,6 & & \\
\hline & 78 & 54,6 & & \\
\hline \multirow{3}{*}{ Ika Aryani } & 90 & 18,0 & \multirow{3}{*}{81,70} & \multirow{3}{*}{11} \\
\hline & 84 & 8,4 & & \\
\hline & 79 & 55,3 & & \\
\hline \multirow{3}{*}{$\begin{array}{c}\text { Wage } \\
\text { Wahyudin }\end{array}$} & 80 & 16,0 & \multirow{3}{*}{81,30} & \multirow{3}{*}{12} \\
\hline & 79 & 7,9 & & \\
\hline & 82 & 57,4 & & \\
\hline \multirow{3}{*}{$\begin{array}{l}\text { Mila } \\
\text { Tantri }\end{array}$} & 90 & 18,0 & \multirow{3}{*}{81,00} & \multirow{3}{*}{13} \\
\hline & 70 & 7,0 & & \\
\hline & 80 & 56,0 & & \\
\hline & 90 & 18,0 & & \\
\hline $\begin{array}{l}\text { Nadine } \\
\text { Vanya }\end{array}$ & 80 & 8,0 & 80,60 & 14 \\
\hline & 78 & 54,6 & & \\
\hline & 88 & 17,6 & & \\
\hline Ira Erica & 89 & 8,9 & 80,40 & 15 \\
\hline & 77 & 53,9 & & \\
\hline & 86 & 17,2 & & \\
\hline $\begin{array}{l}\text { Lutt1 } \\
\text { L }\end{array}$ & 70 & 7,0 & 80,20 & 16 \\
\hline & 80 & 56,0 & & \\
\hline Rafael & 80 & 16,0 & 7060 & 17 \\
\hline Venus & 90 & 9,0 & 19,60 & 17 \\
\hline & 78 & 54,6 & & \\
\hline
\end{tabular}


Tabel 7. Hasil Perhitungan pada Microsoft Excel (Lanjutan 2)

\begin{tabular}{|c|c|c|c|c|}
\hline Peserta & NPPP & NBE & TBE & $\begin{array}{l}\text { Ran- } \\
\text { king }\end{array}$ \\
\hline \multirow{3}{*}{$\begin{array}{l}\text { Wirda } \\
\text { Safitri }\end{array}$} & 80 & 16,0 & \multirow{3}{*}{78,90} & \multirow{3}{*}{18} \\
\hline & 76 & 7,6 & & \\
\hline & 79 & 55,3 & & \\
\hline \multirow{3}{*}{$\begin{array}{l}\text { Steven } \\
\text { Leonard }\end{array}$} & 80 & 16,0 & \multirow{3}{*}{78,80} & \multirow{3}{*}{19} \\
\hline & 89 & 8,9 & & \\
\hline & 77 & 53,9 & & \\
\hline \multirow{3}{*}{$\begin{array}{l}\text { Anton } \\
\text { Kristen }\end{array}$} & 80 & 16,0 & \multirow{3}{*}{78,20} & \multirow{3}{*}{20} \\
\hline & 90 & 9,0 & & \\
\hline & 76 & 53,2 & & \\
\hline \multirow{3}{*}{$\begin{array}{c}\text { Lavinia } \\
\text { Putri }\end{array}$} & 80 & 16,0 & \multirow{3}{*}{78,00} & \multirow{3}{*}{21} \\
\hline & 60 & 6,0 & & \\
\hline & 80 & 56,0 & & \\
\hline \multirow{3}{*}{$\begin{array}{l}\text { Shakila } \\
\text { Agustina }\end{array}$} & 85 & 17,0 & \multirow{3}{*}{77,90} & \multirow{3}{*}{22} \\
\hline & 84 & 8,4 & & \\
\hline & 75 & 52,5 & & \\
\hline \multirow{3}{*}{$\begin{array}{c}\text { Rina } \\
\text { Handayani }\end{array}$} & 85 & 17,0 & \multirow{3}{*}{77,50} & \multirow{3}{*}{23} \\
\hline & 80 & 8,0 & & \\
\hline & 75 & 52,5 & & \\
\hline \multirow{3}{*}{$\begin{array}{c}\text { Tantia } \\
\text { Tatyana }\end{array}$} & 88 & 17,6 & \multirow{3}{*}{76,60} & \multirow{3}{*}{24} \\
\hline & 100 & 10,0 & & \\
\hline & 70 & 49,0 & & \\
\hline \multirow{3}{*}{$\begin{array}{l}\text { Rana } \\
\text { Sonya }\end{array}$} & 80 & 16,0 & \multirow{3}{*}{76,40} & \multirow{3}{*}{25} \\
\hline & 79 & 7,9 & & \\
\hline & 75 & 52,5 & & \\
\hline \multirow{3}{*}{ Erin Myra } & 90 & 18,0 & \multirow{3}{*}{76,20} & \multirow{3}{*}{26} \\
\hline & 85 & 8,5 & & \\
\hline & 71 & 49,7 & & \\
\hline & 95 & 19,0 & & \\
\hline Rosman & 80 & 8,0 & 76,00 & 27 \\
\hline & 70 & 49,0 & & \\
\hline & 80 & 16,0 & & \\
\hline $\begin{array}{l}\text { Nov1 } \\
\text { Farida }\end{array}$ & 80 & 8,0 & 73,00 & 28 \\
\hline & 70 & 49,0 & & \\
\hline & 80 & 16,0 & & \\
\hline $\begin{array}{c}\text { Jayadi } \\
\text { Manulang }\end{array}$ & 100 & 10,0 & 71,50 & 29 \\
\hline & 65 & 45,5 & & \\
\hline & 80 & 16,0 & & \\
\hline Mariadi & 90 & 9,0 & 67,00 & 30 \\
\hline & 60 & 42,0 & & \\
\hline
\end{tabular}

Sedangkan untuk hasil perhitungan seleksi algoritma Multifactor Evaluation Process pada sistem tertera pada gambar 10 sebagai berikut:

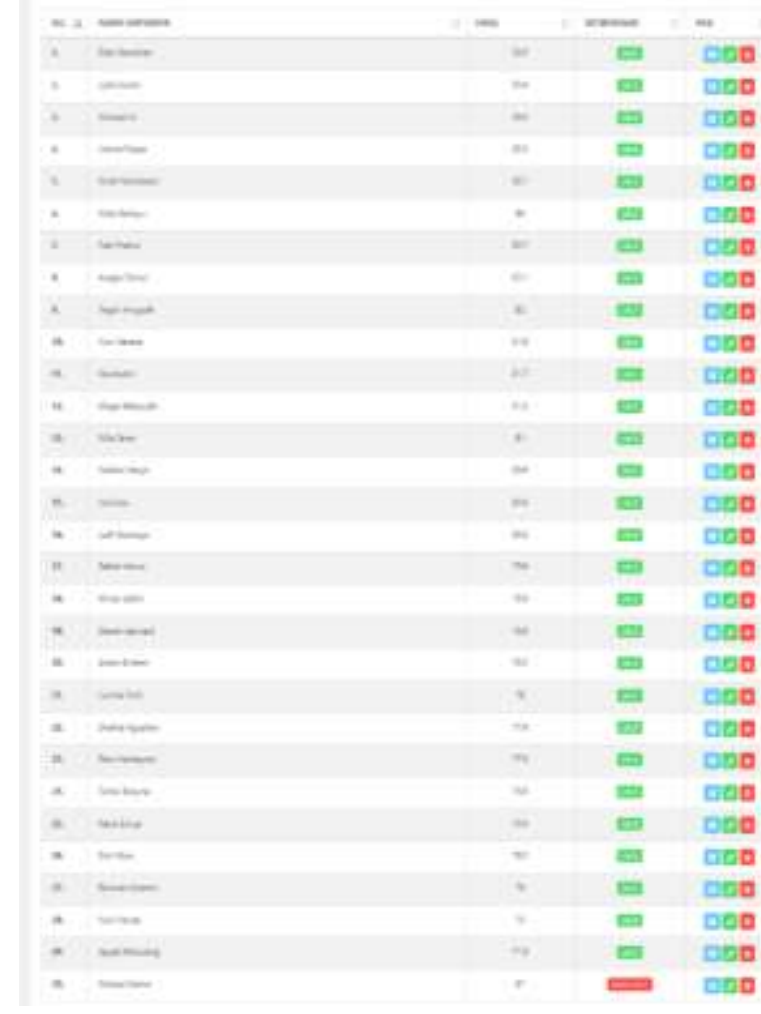

Gambar 10. Hasil Perhitungan pada Sistem

\section{PENUTUP}

Berdasarkan penelitian dengan tahapantahapan yang telah dilakukan, dapat diambil kesimpulan sebagai berikut:

1. Sistem yang dibuat dengan metode pengembangan extreme programming dan algoritma Multifactor Evaluation Process ini berhasil dibangun dan menghasilkan rekomendasi calon karyawan yang layak diterima untuk membantu pihak perusahaan mengambil keputusan. Hal ini berdasarkan hasil pengujian fungsional sistem menggunakan metode

black box yang menunjukan berjalannya semua skenario yang telah dibuat.

2. Sistem pendukung keputusan penerimaan karyawan dengan mengimplementasikan algoritma Multifactor Evaluation Process menggunakan 3 kriteria, diuji dengan melakukan perbandingan hasil 
perhitungan pada microsoft excel dengan sistem, dari total 30 alternatif calon karyawan memperoleh tingkat akurasi sebesar $100 \%$.

\section{DAFTAR PUSTAKA}

[1] Kaswidjanti et al. 2019. Metode Multifactor Evaluation Process untuk Seleksi Asisten Laboratorium. Prosiding Seminar Nasional Komunikasi dan Informatika \#3 Tahun 2019: 125-129.

[2] Ningsih et al. 2019. Sistem Penunjang Keputusan Penentuan Pemenang tender Proyek menggunakan Metode Multi Factor Evaluation Process (MFEP) (Studi Kasus: Dinas Pekerjaan Umum dan Perumahan Rakyat Provinsi Bengkulu). Jurnal Rekursif, Vol. 7 No. 2

[3] Pressman, R. S. 2012. Rekayasa Perangkat Lunak Edisi 7. Yogyakarta: Andi.

[4] Wahyudi, A.D. 2016. Sistem Pendukung Keputusan Seleksi Penerimaan Staff Administrasi Menggunakan Metode Profile Matching. Jurnal TEKNOINFO, 10(2), 1- 4. 